\title{
The social purpose of corporations
}

\author{
NIEN-HÊ HSIEH, MARCO MEYER, \\ DAVID RODIN and JENS VAN 'T KLOOSTER
}

Abstract: To think about the purpose of corporations is to think about what corporations are for. In this article, we argue that the concept of a purpose has an important role in thinking about the moral evaluation of corporations. We make three contributions. First, we distinguish different uses of the concepts of social and corporate purpose. Social purpose concerns the contribution that the corporation makes to realising societal goals. Corporate purpose concerns the goals the corporation should actively pursue. Second, we investigate whether corporations ought to serve a social purpose and whether corporations ought to actively pursue their corporate purpose. Third, we explore critically what roles the concepts of social and corporate purpose can fulfil in moral reflection on and of corporations. In particular, we distinguish the constructive, the communicative, and the critical role of social and corporate purpose.

Keywords: Social purpose, corporate purpose, the corporation, market failures, measurement of purpose.

\section{EXECUTIVE SUMMARY}

What are corporations for? This paper provides an analytical review of relevant research on this question, and some thoughts on the moral evaluation of corporations. It distinguishes between the concepts of social purpose and corporate purpose. Social purpose concerns the specific contribution that a corporation makes to realising societal goals. Corporate purpose concerns the goals the corporation should actively pursue.

Related questions of whether corporations ought to serve a social purpose, whether they ought actively to pursue their corporate purpose, and how to articulate, pursue, and measure corporate purpose are explored. Determining social purpose quickly raises difficult political questions. The arguments for a minimalist or a maximalist approach to social purpose are set out and debated. 
The authors conducted interviews with 24 business leaders which highlighted frustration at the vague concept of social purpose and exactly how social and corporate purpose relate to each other. There was broad agreement that corporations should serve some social purpose, but not precisely what this might be.

The authors outline three reasons why societies become entitled to make claims on corporations, based on the principle of reciprocity. Corporations rely on society's legal system for adjudication and protection. They rely on access to scarce resources that might otherwise be deployed elsewhere, and they are a constant source of social and economic disruption as they undertake their business.

Efficiency and market competition are often cited as forces that might steer firms to social purpose, but the paper argues that pervasive market failures suggest that social purpose cannot be left entirely to the corporation. A web of other factors might also obstruct that goal.

Likewise, corporate purpose cannot be determined by the corporation alone due to a lack of 'epistemic competence' or the ability to balance and judge competing stakeholder interests, and the fact that corporations interact within political and social structures. The paper considers the societal responsiveness and shared value approaches to articulating corporate purpose, and the shortcomings of these methodologies.

One of the most complex challenges is the meaningful measurement of corporate and social purpose. Most current measures of corporate purpose are accounting measures. Social purpose also uses holistic action-guiding measures for environmental, social, and governance impacts. However, none is yet satisfactory, and measurement remains 'the most important condition for giving bite to corporate purpose'.

\section{INTRODUCTION}

To think about the purpose of corporations is to think about what corporations are for. In the academic literature, terms such as 'social purpose' and 'corporate purpose' are seldom used, and if they are, they are used with little precision. However, business leaders increasingly use these terms, as we learned from the 24 interviews that we conducted as background to our research. While the interviewees were not selected to be representative, their overwhelming emphasis that social purpose is important provides an interesting contrast to the dearth of explicit theorising on social purpose in the academic literature. Indeed, business leaders expressed unease that the concept of social purpose remains vague and pointed to the need for a clear framework to articulate and measure social purpose. In this paper, we contribute to meeting this need by providing an analytical review of the topic of purpose and arguing that it is a useful 
concept for thinking about what corporations ought to do.

The first contribution of this article is to distinguish the different ways in which the notions of social and corporate purpose are understood, and to differentiate them from related concepts (Section 2). We distinguish social purpose from corporate purpose. Social purpose concerns the contribution that a corporation makes to advancing societal goals. It is possible to make such a contribution without actively pursuing it. Corporate purpose concerns the goals the corporation should actively pursue. We suggest that much of the disagreement pertaining to the topic of the purpose of corporations revolves around different theories of how social purpose and corporate purpose relate to each other.

Our second contribution is to clarify the debate about whether corporations ought to have a social purpose and whether corporations ought to have a corporate purpose (Section 3). There is broad agreement that corporations ought to serve some social purpose, even if there are competing views on what the social purpose of corporations consists in. A major point of contention is whether corporations should directly pursue this social purpose or focus on financial goals instead. We argue that views that seek to entirely dissociate corporate purpose from social purpose rely on strong assumptions about competitive markets which are increasingly unrealistic. But, we also argue that, even if corporations should ensure social purpose, this responsibility cannot be left entirely to the corporation itself. This tension between societal and firm responsibility is at the core of our understanding of social purpose.

The third contribution of the article is to explore how to deal with this tension by asking what role the concept of social purpose can play in practice (Section 4). We distinguish a constructive, a communicative, and a critical role of social purpose, and discuss the ways in which the concept of social purpose can serve these functions.

\section{CONCEPTUAL FOUNDATIONS}

In our interviews with business leaders, we encountered a broad spectrum of views on social and corporate purpose. Some see an organisation's purpose as a source of motivation for themselves and employees. Others regard purpose as a precondition of their right to operate in a country or as the expression of the particular vision of the founder of the corporation. A number of interviewees think of purpose as the most fundamental anchor of their corporate strategy, or as a competitive advantage. Yet others expressed worries that thinking too much about purpose may distract management from pursuing the economic goals of the corporation. There was broad agreement about the need for a conceptual framework navigating these different perspectives on social purpose. We begin the formulation of such a framework by looking more closely at 
the concept of a purpose and distinguishing two different meanings which we refer to as 'social purpose' and 'corporate purpose'. Social purpose concerns the contribution that a corporation makes to advancing societal goals, regardless of whether it directly pursues these goals or advances them as a side effect. By contrast, we use the term 'corporate purpose' to refer to any non-financial social goals that the corporation directly pursues.

\subsection{What is purpose?}

What is the nature of a purpose? Philosophers have held different views on the nature of purpose throughout history. Aristotle and his medieval followers thought of purpose as one of the four defining causes of a natural kind. Thus, for Aristotle, to be a drink literally $i s$ to be something that serves the purpose of quenching thirst. On this perspective, identifying a purpose is a matter of discovering something about the nature of things.

This realist view of purpose was called into question by early modern philosophers such as Hobbes and Spinoza. They maintained that the purpose of a thing exists only relative to the interests of an agent. A taxi has no purpose if there has never been anyone who desired to be moved around. To find out about a purpose of something we need to know more about the people who desire to use it. What are their preferences and interests? It is these agential properties that determine the purpose of things. This view emphasises the constructive role of the subject in assigning a purpose to things. To identify a purpose is to discover something about the ways things are perceived to be useful.

The latter perspective provides a better guide to investigating the social purpose of corporations because it can readily make sense of disagreements over what the purpose of a corporation is. People will value what a corporation does or might do for different reasons. Is the purpose of a supermarket to provide a wide variety of high-quality products to customers? Or should a supermarket focus on locally sourced products to achieve its environmental purpose? Is part of the purpose of a supermarket to provide meaningful work to employees? The realist perspective suggests that there is one correct answer to these questions and in this sense does not recognise the fact of reasonable disagreement (Rawls, 1996). For our interests here it is important that purpose is a topic on which people indeed disagree and therefore use a constructivist vocabulary to talk about purposes. 


\subsection{What is a social purpose?}

Societies can be seen as complex social systems. Different parts of social systems, such as politics, science, or education, can be differentiated along functional lines (Habermas 1985, Luhmann 1977). Subsystems operate according to specific rules in order to serve particular purposes. The question of the social purpose of corporations concerns the role that corporations ought to serve within a social system. The social purpose of a corporation is the specific contribution it makes to advancing societal goals.

Our focus in the following will be on the topic of social purpose as it applies to corporations. The 'corporation' is a type of legal entity that provides a framework for individuals to organise joint activities. In business corporations, these activities are aimed towards the production of goods and services. Often corporations are defined even more narrowly as organisations whose (private) purpose is to make profits for owners and shareholders (Blair 2003, Ciepley 2013, Stout 2012). But this narrow definition neglects that corporations take a wide variety of legal forms, including not just the publicly listed limited liability company (Blair 2003), but also state-owned enterprises (Detomasi 2015, Scherer et al. 2016), social enterprises (Santos 2012), benefit companies (Vaughan \& Arsneault 2018), and cooperatives (Cheney et al. 2014). Regardless of their specific legal form, all corporations are legal persons in their own right (Hansmann et al. 2006). Corporations have a right to own property, to enter into contracts, and to sue others in court. The corporation shares these traits with a wide range of public and private organisations. The feature that we take to set business corporations apart from those organisations is their role in production and exchange of goods and services.

On the most abstract level, regardless of whether organisations produce soft drinks, spin social networks, or organise taxi rides, the purpose of corporations is to facilitate valuable activities, such as the production of valuable goods and services in the case of businesses. But corporations do not only produce value for customers. For instance, corporations also provide employment, which provides people with an income but can also support personal development and a sense of meaning. Corporations can also serve as investment vehicles for their owners or shareholders. All these things together inform the social purpose of corporations. A corporation has a social purpose in the sense that we are interested in if it contributes to advancing societal goals.

In the rest of the article we explore the concept of social purpose and show that it can do important work in moral reflection on corporations. Consider now four aspects of how we understand the topic of social purpose. 
First, the concept of social purpose is compatible with different ways of demarcating the 'society' that the corporation is useful for. Although national borders retain some role in demarcating social structures, corporations often have a purpose for social structures that do not track these borders. Large MNCs (multinational corporations) can be seen as a part of a global society, whereas smaller firms have a social role that is tied to much more local structures.

Second, although reflection on social purpose often leads to consideration of a wide range of stakeholders, the concept is entirely independent of the stakeholder framework. Stakeholder demands and interests can be thought of as one way to analyse the different functions that a corporation plays for society. Stakeholders are the different groups of individuals who have an interest in the activities of the corporation. Traditionally, stakeholders are shareholders and other beneficiary owners, management, employees, customers, and other affected individuals. Analysing the potential impact of a corporation on different stakeholders is often an insightful way of categorising the different purposes of corporations. But, there are many ways in which to group the individuals for whom a corporation has a purpose. Nothing about the topic of social purposes implies the need for the vocabulary of stakeholders. Moreover, as we will discuss in more detail in Section 3, the corporation can make contributions to social purpose without actively pursuing these. For a corporation to have a social purpose it need not actively manage the interest of stakeholders.

Third, the social purpose of a corporation is something that people disagree on. Is Facebook's purpose to connect people, or does it also include a commitment to protect the privacy of users? Identifying the social purpose of a corporation requires recognising the fact that different private purposes may conflict. For instance, the goals of providing a wide selection of vegetables and of sourcing locally may conflict. Importantly, as we bring out in Section 3, the corporation itself is often not the most suitable place in which to solve these big societal questions concerning ultimate societal goals.

Finally, not all corporate activities that have a private purpose thereby also have a clear social purpose. For example, there is a considerable segment of complex financial products that is bought by less sophisticated customers and has lower return than simpler financial products (Célérier \& Vallee 2015, 2013, Zingales 2015). The main purpose of their complexity seems to be duping consumers into buying low-quality financial assets. More generally, a corporation can do better or worse in fulfilling the societal expectations that determine its purpose. A social purpose explains how a corporation's operations contribute to the different ends that society and its members pursue. 


\subsection{What is corporate purpose?}

It is crucial to distinguish social purpose from what we will refer to as 'corporate purpose'. Corporate purpose consists in the overarching management objectives of a corporation that go beyond narrow financial metrics, such as providing good work, contributing to sustainable economic development, or fostering consumer autonomy. Hence a corporation that is exclusively managed to maximise profits does not have a corporate purpose in our usage of the term. The key difference between social purpose and corporate purpose is that corporate purpose concerns the intentions and ambitions of corporations, whereas social purpose is an analytical concept to describe the actual societal contributions corporations make.

Pursuing a corporate purpose is compatible with pursuing profits. However, the concept of corporate purpose should be distinguished from that of shared value. Shared value approaches suggest that corporations should pursue opportunities that generate profits while also producing value for society (Dembek et al. 2016, Porter \& Kramer 2011). Here, the pursuit of narrow financial objectives goes together with the pursuit of purpose. Most corporation will be able to pursue at least some financial aims by also aiming for broader societal goals. But the pursuit of corporate purpose is not always also the most profitable strategy and there is often a serious question of how to prioritise different ends. If maximising financial benefits conflicts with societal goals, a corporation with a strong corporate purpose will give considerable weight to societal goals.

The questions of whether a corporation should have a social purpose and whether it should have a corporate purpose are distinct. On some views, corporations ought to serve a social purpose, but serving their social purpose does not require them to have a corporate purpose. Proponents of this view may maintain that pursuing financial objectives (rather than corporate purpose) steers corporations towards their true social purpose of making efficient use of societal resources.

It is also possible to deny that corporations ought to serve a social purpose, yet to maintain that corporations ought to have a corporate purpose. For instance, someone unconvinced by the social purpose of corporations may still maintain that some corporations should voluntarily adopt a particular corporate purpose to meet customer preferences for 'ethical products'.

A lot of disagreement arises because social purpose and corporate purpose are not clearly distinguished. Even if there is wide disagreement over what is actually socially purposeful, there is far less disagreement over whether corporations ought to serve a social purpose. This is assumed to be the case even by economists who maintain that corporations in aggregate will achieve their social purpose by individually pursuing profit in a competitive market environment. We will return to the merits of such views 
below. For now, what matters is the conceptual distinction between social purpose and corporate purpose. Once we agree on the social purpose of corporations, there is the further question of corporate purpose.

\section{NORMATIVE FOUNDATIONS}

Our interviewees overwhelmingly endorsed the importance of purpose. They recognised the fundamental notion of social purpose as a meaningful category for the evaluation of corporate activities. They also acknowledged the importance of corporate purpose. While some saw corporate purpose as external to the core business of the corporation, to be discharged via volunteering or charitable giving, most agreed that the pursuit of non-financial goals has to underpin the core activities of the corporation.

We will now outline a normative foundation that justifies these moral judgements. We first investigate why we should assume that a corporation should serve a social purpose. We then turn to the topic of corporate purpose, where we show that the moral issues are much less straightforward. Against those who hold that corporations should aim narrowly for profits, we argue that mere market competition cannot be assumed to realise social purpose. Through a critical discussion of Joseph Heath's market failures approach we show that, because capitalism is a system of constant growth, the operations of firms continuously raise complex moral issues that cannot be reduced to the efficient allocation of resources. But, we also show that the role of a corporation in dealing with these moral issues must be limited, as the corporation is not the appropriate site for the required deliberation. Thus, although corporate purpose has an important role in ensuring that the operations of an activity are useful from a societal perspective, the responsibility for social purpose cannot be left to the corporation alone.

\subsection{Ought corporations to serve a social purpose?}

Let us first turn to the question of whether corporations ought to serve a social purpose. If it turns out that this is not the case, as some libertarians would argue, then it is questionable what value the concept has. We therefore explore the nature of the libertarian challenge and outline two ways of responding.

The libertarian position does not deny that corporations may and often do in fact generate substantial social benefits. What the libertarian rejects is that corporations are under any moral obligation to serve a social purpose. Instead, libertarians see corporations as legal entities allowing individuals to enter into various forms of 
voluntary association (Hasnas 1998, Marcoux 2003, Sollars 2002). Just as individuals are not obliged to serve a social purpose, corporations should not be held to such a standard either. The reason is that restricting corporate activities to those deemed socially purposeful would restrict the range of possible associations individuals can enter in the form of a corporation. Restricting corporations to socially purposeful activity means restricting the freedom of individuals as well.

There are two important arguments why corporations should serve a social purpose. The first argument challenges the libertarian idea that corporations are mere vehicles for individuals to form voluntary associations. The rebuttal emphasises the legal autonomy that a firm has in relation to any natural person (Ciepley 2013, Orts 2015, Stout 2012). The legal autonomy of corporations sets them apart from any one plan of action pursued by an individual. For a wide range of questions, a corporation is an agent deciding freely over the use of its productive assets and exercising authority over its employees. For example, the role of shareholders in publicly traded companies does not fit well with the libertarian idea of an autonomous exercise of the will (Stout 2012). Both the control shareholders have over the firm and the responsibilities they bear are limited. For instance, shareholders cannot withdraw funds from the firm. At best, they can sell their shares to someone else. The legal form of the corporation also separates the financial positions of the corporation and its shareholders. Bankruptcy of the corporation does not carry over to the shareholder. Conversely, bankruptcy of the shareholder does not impose costs on the firm. There is considerable debate on how to conceptualise the relation between personal and collective responsibility, but most authors now agree that a least some responsibilities are held at the collective level (Hess 2017; for an overview of recent debate, see Orts $\&$ Smith 2017). Given the considerable autonomy of the corporation as an agent, it cannot be treated as a mere private association that allows its members to exercise their freedom.

The first argument denies the view that corporations are to be understood in close analogy to human beings. Proponents of this argument can grant that individuals do not have to serve a social purpose. Proponents can also grant that the autonomy of individuals is of value because it is an important precondition for human freedom. Their use of societal resources and recourse to the legal system is justified because it enables them to live a free life. In Kantian terms, this insight is formulated in terms of the idea that human beings are ends in themselves (Altman 2007). But proponents deny that this argument carries over to corporations. Corporations have little or no intrinsic value. Instead, what corporations do is to coordinate the actions of several-and sometimes very many-people to achieve certain goals. Corporations are not ends in themselves. This makes the moral status of the corporation distinct from the individuals whose actions it coordinates and the stakeholders whose interests are affected. 
Note that the first argument merely opens up the possibility of imposing obligations on corporations to serve their social purpose by rebutting the libertarian argument. The first argument does not provide a positive argument as to why corporations should serve a social purpose.

The second argument makes a positive case for requiring corporations to serve a social purpose. The argument is based on the idea of reciprocity (Becker 1998, Gibbard 1991, Rawls 1996). Corporations rely on social resources and infrastructure for their existence and continued operation. Their existence is only possible through a societal licence and continued support. In return, the operations of the corporation should have sufficient value for the society in which they operate (Bishop 2008, Brock 1998, Donaldson 1982, Hsieh 2015).

Consider three distinct ways in which societies become entitled to make claims on corporations based on reciprocity. First, the corporation can only effectively operate because it has recourse to the legal system. The legal system provides adjudication where the corporation's legal claims conflict with those of others. Moreover, citizens, as a rule, respect legal claims, and where they do not the state enforces the corporation's legal claims. Individuals are entitled to participate in the legal system because it secures their fundamental rights but, as we discussed just now, there are no similarly pressing reasons why corporations should have rights.

Second, corporations rely on access to scarce resources. For instance, corporations require well-trained employees, capital, technology, and natural resources. If these resources are used by a corporation, they cannot be used in other ways.

Third, corporations are a constant source of social and economic disruption. When corporations innovate, societies need to use their scarce political resources to deal with the consequences and make adaptations where necessary.

Because operations of corporations are enabled by social resources and infrastructure, corporations should serve a social purpose as a matter of reciprocity.

We have presented two arguments why corporations ought to serve a social purpose. The first argument debunks the libertarian case against social purpose. The second argument provides a positive reason why corporations should serve a social purpose. We do not purport to settle the substantive argument between libertarians and proponents of social purpose here. However, we note that the lines of argument that we put forward are widely shared and also fit with the views that our interviewees put forward. This further illustrates the usefulness of the concept.

\subsection{Ought corporations to have a corporate purpose?}

Let us now consider whether corporations ought to have a corporate purpose, and what that purpose consists in. Recall that corporate purpose is any overall management objective to be pursued alongside financial metrics and that aims at a social objective. 
In the following, we focus on corporate purpose that goes beyond the corporation's role in charitable activities in the community, and other forms of corporate social responsibility and corporate citizenship that are tangential to the core of the business model (Néron \& Norman 2008).

As we have shown, it does not follow from the commitment to social purpose that corporations ought to have a corporate purpose. Minimalist positions maintain that corporations ought not to pursue non-financial objectives because social purpose is best served if corporations focus on the pursuit of financial goals (Friedman 1970, Heath 2014, 2004, Jensen 2005, Sundaram \& Inkpen 2004). In a slogan, the view is that the only responsibility of the corporation is to make a profit. Not even Milton Friedman, to whom the view is often attributed, endorsed this position without qualification (Bruin 2015). Rather, he stated that the corporation should 'use its resources and engage in activities designed to increase its profits so long as it stays within the rules of the game, which is to say, engages in open and free competition, without deception or fraud' (Friedman 1970).

To explain why we find minimalist conceptions of corporate purpose deficient, we focus on Joseph Heath's 'Market Failure Approach', which stands out because it starts off with a conception of social purpose (Heath 2004, 2014). Invoking an account of the corporation as realising an efficient allocation of resources, Heath also provides a sustained argument why corporations should not attempt to promote social purpose directly. Our critique of Heath allows us to show that (i) the social purpose of the corporation cannot be reduced to that of realising an efficient allocation of resources and, therefore, (ii) that the mere striving for profits is not the best way to realise the corporation's purpose.

Market actors such as corporations, Heath argues, are not accountable to the moral demands that the economic system as a whole must satisfy. Corporations are given licence to maximise profits because, in reasonably competitive markets, this is thought to be the best way to promote social purpose. Hence, corporations fulfil their social purpose by maximising profits. To evaluate the argument against corporate purpose, we need to understand why competitive markets might steer profit-maximising firms to serve their social purpose best.

The first assumption in Heath's argument is that the social purpose of corporations is to realise an efficient allocation of resources. Economic efficiency is defined in terms of Pareto optimality. A distribution is Pareto optimal if there is no alternative distribution that makes at least one person better off without making at least one person worse off. Why would economic efficiency be socially beneficial? There is a quick argument why, other things being equal, economically efficient distributions are to be preferred to inefficient ones. All this argument assumes is the moral principle of minimal benevolence. According to minimal benevolence, for any individual, it is morally better if this individual is better off, other things being 
equal (Hausman et al. 2016). It follows that a distribution that is Pareto superior to another distribution is morally better. The reason is that, by definition, the Paretosuperior distribution leaves everybody at least as well off and makes at least one person better off.

But economic efficiency may come into conflict with other criteria of economic success. Economic efficiency is a feature of economies at a given point in time. In testing for efficiency, we are considering a snapshot of the economy, and asking whether there are ways of improving the given situation without making anyone worse off. Efficiency, then, needs to be distinguished from dynamic progress. A dynamically progressive economy is one that grows, increasing the volume of assets available for distribution.

There is no conceptual link between economic efficiency and dynamic progress. Hence, an economy may be inefficient yet dynamically progressive, as well as efficient yet lacking in dynamical progress. It is not obvious at all from an economic standpoint why we should be more impressed with efficiency than with dynamic progressiveness. The main reason that welfare levels in capitalist societies have so dramatically increased compared to two hundred years ago is that these economies have continuously grown. This reflects the great dynamic progressiveness of capitalist societies, rather than their efficiency. For designing and regulating markets, it is of critical importance to identify the social purposes that corporations ought to serve in a way that is sufficiently inclusive. New products do not always meet existing customer demand, but sometimes shape customer preferences. The aim of pursuing efficiency is of little use to engineers at Tesla or Amazon, who ponder how to design self-driving cars or delivery drones. Nor will it be of much help to regulators who worry about licensing these new products. But questions of social purpose are not only relevant for cutting-edge tech companies. Virtually all companies ask questions which cannot be answered in terms of Pareto efficiency, such as what quality of products and services to offer, which sales practices to adopt, how to treat staff, which customer groups to target, where to produce, and many others. Answering these questions requires reflection on values such as autonomy, freedom, access to livelihood, and good work, as values that corporations can help realise (Hsieh 2017).

If we recognise other goals than economic efficiency, Heath's argument against corporate purpose breaks down. It is hardly plausible, for instance, that a corporation aiming at narrow financial indicators will thereby promote autonomy or good work.

We also want to challenge Heath's second assumption, which is that markets are special-purpose institutions to steer profit-maximising corporations towards economic efficiency. Here, Heath puts forward a view that is widely shared by minimalists. 
Heath recognises that most economic distributions that are efficient are not thereby just or otherwise desirable from a social perspective. But Heath maintains that in competitive markets, it is the role of the welfare state, particularly the tax system, to promote an equitable distribution among the many possible efficient distributions.

The second welfare theorem underpins Heath's thesis that efficiency and equity can be functionally separated. The second welfare theorem implies that, whatever efficient outcome you want to achieve, non-distortive taxes and transfers push the economy to settle on this distribution. The theorem suggests a division of labour between corporations and the state. Corporations pursue profits to achieve efficiency, and the state ensures that economic benefits are distributed equitably. Hence corporations ought not to pursue corporate purpose in perfectly competitive markets.

Heath's argument requiring corporations to focus only on the pursuit of profits holds only in perfectly competitive markets. Markets are perfectly competitive if both buyers and sellers are sufficiently numerous and well informed that no market participant can control the price at which goods are sold. In perfectly competitive markets transaction costs are zero, products are undifferentiated, and there are no barriers to entry and exit. There are also no information asymmetries in perfectly competitive markets, and all costs and benefits generated by a transaction fall only on the contracting parties.

Many actual markets are clearly far from perfectly competitive. For instance, information asymmetries between banks and their customers enable banks to charge higher prices than they could in perfectly competitive markets. Big tech companies like Facebook and Google enjoy enormous market power because the network character of their products creates high barriers to entry. Airlines and their customers do not internalise all costs of flying but shift some of the environmental damage onto all of society, including future generations. To appreciate how radically existing markets deviate from perfectly competitive markets, consider that profits in perfectly competitive markets are zero in the long run. The reason is that, if a market generates profits, more firms will enter the market and bid the price down until profits are zero. Yet there are very few industries which run anywhere close to zero profits. Heath maintains that in non-competitive markets, the corporation should behave as it would in a perfectly competitive market. For instance, it should not take advantage of information asymmetry or monopoly power. Hence he acknowledges a limited role for corporate purpose. Corporate purpose consists in pursuing Pareto-optimal outcomes even if that does not maximise profits because markets are not fully competitive. Corporations, according to Heath, ought to correct market failures.

We think that perfectly competitive markets are often not the appropriate paradigm for reflecting on social purpose of corporations. In imperfect markets, the best way to improve social outcomes may often not be to approximate perfect competition. It 
follows from the 'theory of the second best' that removing some but not all market failures often leads to less rather than more efficient outcomes (Lipsey \& Lancaster 1956). Eric Harsch, CEO of the German drugstore DM, explained to us in an interview that he takes the welfare and development of his employees to be more important than either profits or low prices for customers. In a perfectly competitive market, pursuing any other goals than profit maximisation should price corporations out of the market in the long run. Since the German retail market is not a perfectly competitive market, DM can pursue another candidate component of corporate purpose, namely good work. This example illustrates that exploiting some market imperfections may enable corporations to serve their social purpose better.

In sum, the minimalist view that sees the role of the corporation as limited to the pursuit of profits while not exploiting market failures is too narrow. This allows it to deny that a corporation should develop its own conception of its purpose in a way that goes beyond narrow financial metrics. We have raised two objections to Joseph Heath's moderate form of minimalism. First, he equates the social purpose of the corporation with that of realising an efficient allocation of resources, but, as we argue, there is in fact a much wider range of purposes that corporations pursue. Second, irrespective of what the social purpose of a given corporation turns out to be, it cannot be assumed that removing market imperfection is the best way to ensure that the corporation serves that purpose.

We now turn to maximalist conceptions of corporate purpose, which maintain that the corporation realises its social purpose best by actively pursuing it. Stakeholder theorists endorse this position insofar as they maintain that corporations should be managed to realise a fair treatment of the interests of all those affected by their operations. The firm is to 'focus on how value gets created for each and every stakeholder' (Freeman et al. 2010: 9). There are now several competing forms of Stakeholder Theory, including corporate citizenship (Logsdon \& Wood 2002, Néron \& Norman 2008, Scherer \& Palazzo 2007) and views drawing on particular moral traditions, such as Kantian ethics (Arnold \& Harris 2012), virtue ethics (Koehn 1995, Solomon 1993), social contract theory (Dunfee 2006), or Confucianism (Kim \& Strudler 2012). What these maximalist approaches share is the view that social purpose is something that corporations themselves ought to pursue.

The debate between minimalist and maximalist positions concerns whether the best way of achieving social purpose is to pursue this purpose directly. Minimalists maintain that regulators ought to set incentives to steer corporations towards their social purpose, on the condition that they pursue profits. Both sides agree that corporations should serve a social purpose, but have very different views on corporate purpose.

This maximalist view is closely related to a view, which we often encountered in our interviews, which holds that corporate purpose is something that the corporation 
itself determines. This assumption also informs a part of the business ethics literature, where the locus of deliberation is often implicitly assumed to be the firm itself. But when it comes to the big questions of corporate and social purpose, this may not be the most promising approach. Consider three arguments that count against leaving decisions on purpose entirely to corporations.

First, there are good reasons to doubt whether firms are able to adjudicate competing interests in a fair way. For one thing, there is an issue of incentives and motivation. The coordination of the economy through markets fosters competition in a way that often goes against a measured weighing of interests. There is also an issue of epistemic competence. Firms will lack the information to know how to adjudicate the interests of its shareholders, employees, and customers.

Second, identifying a corporate purpose is a large burden, which should not be placed on corporations alone. Individual corporations are part of a functionally differentiated subsystem of society (Habermas 1985, Luhmann 1977). This subsystem is embedded in political and social institutions that seek to regulate the private sphere and protect those interests that are not adequately protected by it (Granovetter 1985, Polanyi 2001). The social responsibility of firms cannot be determined without considering the basic structure of social and political institutions that they are part of (Heath et al. 2010, Hsieh 2017, Rawls 1999).

Finally, setting a corporate purpose sometimes has political repercussions that a corporation's management lacks the legitimacy to make. As recent shareholder theorists are right to point out, 'What is the social, economic, and political legitimacy of a manager to choose? Who oversees and legitimates these choices?' (See also Hsieh 2017, Sundaram \& Inkpen 2004.)

Leaving it to corporations alone to determine their corporate purpose involves a fallacy of composition. Each corporation pursuing a corporate purpose may not lead to corporations as a whole creating social value. Instead, the best way to secure the social purpose of the corporation involves different responsibilities for individual corporations, regulators, and other societal institutions. We now turn to the question of what role the concepts of corporate and social purpose can serve in deliberation on these questions.

\section{MANAGING FOR PURPOSE}

In this section, we distinguish three functions that deliberation on purpose can serve: the constructive function of guiding corporate strategy and regulation, the communicative role of managing the relationship of corporations with society, and the critical role of evaluating the performance of corporations beyond financial indicators. 
Purpose serves a constructive function if regulators design markets and regulation to steer corporations towards their social purpose, and if corporations articulate their corporate purpose to support their social purpose, embedding their corporate purpose into different aspects of their operations, including their product development, business model, and organisational culture. The communicative function is for corporations to negotiate with governments, regulators, and civil society about what contribution the corporation should make to society. The critical function allows corporations to monitor their contribution to society and allows society to criticise corporations that fail to achieve their purpose or engage in activities that manifestly undermine their purpose.

We should be aware that corporations may invoke purpose rhetoric to dress up their operations. If so, social purpose risks becoming a mere marketing buzzword (Dembek et al. 2016). It will then obscure the moral landscape by dignifying corporations with a purported purpose they fail to live up to. Or, at the very least, distract the corporation's attention from its economic objectives.

In this section, we lay out what it would take for society and corporations to take purpose seriously. We do this through a critical review of existing tools available in the business ethics literature and making suggestions on how this literature can be extended to accommodate reflection on purpose.

\subsection{The constructive function of social and corporate purpose}

For regulators and other societal actors, the constructive function consists in steering corporations towards meeting their social purpose. For corporations, the constructive function consists in articulating a corporate purpose that is consistent with the corporation's social purpose and to consistently embed their corporate purpose in the organisation's operations, strategy, and organisational culture. All of these functions are currently insufficiently theorised. A fully developed social purpose approach will be able to guide corporations and societal actors to work out the proper role of corporations in society.

Let us first turn to the constructive role of social purpose from the perspective of societal actors. Corporations develop their corporate purpose within a regulatory framework. The role of regulators and other political actors is to design markets and regulation to steer corporations towards socially desirable outcomes.

Articulating the social purpose of corporations involves a complex interactive process. One crucial question is what role corporations themselves should have in this process. The classical liberal view is that the corporation should stay out of the political process (Friedman 1970, Jensen 2005). Others suggest that corporations can take a role in the political process on an equal footing with citizens (Néron \& Norman 2008), or 
that corporations can act to support the political process (Christiano 2010, Néron 2016). Finally, there are those who see corporations themselves as sites of political deliberation, in isolation from and sometimes in opposition to the government (Crane et al. 2008, Scherer \& Palazzo 2011, Scherer et al. 2016). We need an account of the political role of corporations in democratic societies, realistically understood.

Let us now turn to the constructive role of corporate purpose within corporations. There is little academic literature on the steps that organisations take in articulating their purpose. The prevailing frameworks that a fully articulated framework can draw on are stakeholder management (Mitchell et al. 1997), social responsiveness (Wood 1991), and the shared value approach (Porter \& Kramer 2011).

Stakeholder management suggests proceeding in three steps: first, identifying the relevant stakeholders of a corporation; second, determining the interests of stakeholders; third, articulating the benefits the corporation brings to each stakeholder group. The social responsiveness approach asks corporations to identify societal issues on which their operations have a bearing. Societal issues that are often discussed are gender equality, ecology, and inequality. In a second step, corporations are asked to articulate the ways in which they seek to address these challenges. The shared value approach proposes to identify areas where a given corporation can profitably create social values. This requires identifying, first, the areas in which the corporation has the expertise and resources to operate profitably. Second, the corporation selects the profitable areas where it can simultaneously create value for society.

All three methodologies may play some part in articulating a corporation's social purpose. But all approaches share two fundamental shortcomings. First, they do not fully confront the question of what the corporation is. The stakeholder approach replaces the question of corporate purpose with the question of how the corporation benefits its stakeholders. The social responsiveness approach focuses on the question of how the corporation can influence major societal issues. The shared value approach seeks to determine where the economic interests of the corporation and the interests of society overlap.

The second shortcoming is that methodologies address the management of corporations as arbiters of corporate purpose. In the previous section, we have discussed to what extent the corporate purpose of a given organisation can be 'read off' the social purpose of corporations in general. We identified reasons to doubt that corporate purpose can simply be deduced from the social purpose of corporations, and that corporations can determine their purpose at will. But existing methodologies fail to address how regulators and societal stakeholders get an appropriate say in articulating corporate purpose. 
Developing a methodology to articulate corporate purpose can fruitfully proceed by integrating the existing approaches in the literature with the developing practice in corporations. Currently, conceptual and methodological questions in articulating their purpose are resolved unwittingly or with little consideration of possible alternatives. For instance, should corporations be guided by the legacy of the business, or by its current or potential future capabilities? Do corporations have one overarching corporate purpose, or do they serve different purposes? If the latter, should purposes be differentiated by lines of business or by products? Is corporate purpose to be identified inductively by analysing the benefits of diverse corporate activities? Or should a conception of purpose be formulated top-down and shape operations to conform to that purpose? Which internal and external stakeholders should be involved in articulating corporate purpose? A methodology for articulating corporate purpose within the constraints of social purpose would help resolve these outstanding issues.

\subsection{The communicative role of social and corporate purpose}

The communicative role of social and corporate purpose is to enable a differentiated normative debate about the proper goals of corporations and the social harms and benefits they are generating. Articulations of social and corporate purpose can serve as the starting point to find common ground between different accounts of the proper role of particular corporations in society, and to debate whether the corporate purpose of a corporation is consistent with its social purpose.

How much say should regulators and politicians on the one hand, and corporations on the other hand have in settling questions about the proper purpose of corporations? This question is intimately connected to the deep moral question concerning the political legitimacy of the corporation. On the classical liberal perspective, issues of corporate purpose are to be left to corporations (Friedman 1970, Jensen 2005). Corporate activity belongs on the private side of the private/public distinction and should, therefore, be protected from government interference.

However, business ethicists have recently started to challenge this classical liberal perspective (Ciepley 2013, Heath et al. 2010, McMahon 2012, Néron 2010). In their view, corporate activity belongs at least partly on the public side of the private/public distinction and hence needs to live up to standards of political legitimacy. The topic of social purpose and the wide range of moral question that corporations face require a more extensive reflection on political legitimacy.

If decisions on corporate purpose are indeed partly political, we need to resolve how these questions are to be resolved legitimately. For instance, central banks derive their legitimacy from a mandate conferred on them by governments. Historically, such a mandate was required of all corporations, so that only those corporations whose 
operations were deemed sufficiently socially valuable were permitted to operate within national borders. Recent theorists of the corporation have sought to revive such thinking (Anderson 2017, Ciepley 2013, Stout 2012).

Note that the communicative role of social and corporate purpose is not only relevant for the relationship of corporations with society, but also within corporations. Leaders typically encounter challenges in connecting a given articulation of corporate purpose with the day-to-day operations of the firm. This challenge is a predictable outcome of involving only a small group of executives in the process of articulation. Our interviewees report that the first challenge they face is to communicate corporate purpose internally. Enabling employees to pick out their corporate purpose among several alternatives is a multi-year effort in large organisations.

It is a further step to truly embed corporate purpose in corporate decision-making. Our interviewees report the most immediate impact of corporate purpose on senior leader decision-making. Corporate purpose can serve as a yardstick enabling members of the organisation to challenge decisions, appealing to a mutually recognised standard.

Stakeholder management, social responsiveness, and shared value approaches may all be useful in connecting corporate purpose with the day-to-day operations of the firm. All three approaches can be seen as heuristics to concretise high-level purpose statements. For instance, the stakeholder approach may be used to work out the implications of corporate purpose for employees, customers, shareholders, and other stakeholder groups.

But a fixation on corporate purpose without factoring in the costs that the corporation imposes on society can be problematic. In 2016, Andrew Bosworth, who is part of Facebook's inner circle, wrote a memo addressing the downsides of Facebook's corporate purpose. Bosworth says that 'we believe in connecting people so deeply that anything that allows us to connect more people more often is de facto good. ... That isn't something we are doing for ourselves. Or for our stock price (ha!). It is literally just what we do. We connect people. Period' (Buzzfeed 2016).

Bosworth appeals to purpose to justify the fact that Facebook can be used for online bullying and for planning terrorist attacks. Remarkably, he also claims that questionable corporate practices are justified in the light of Facebook's purpose, including '[a]ll the questionable contact importing practices. All the subtle language that helps people stay searchable by friends. All of the work we do to bring more communication in.'

Bosworth's memo brings out that pursuing corporate purpose may have a dark side: namely, disregarding the costs corporations impose on society in pursuing their purpose. A decision-making framework based on corporate purpose should not only consider the value created for society. The framework should also consider 
costs to society and point out ways of balancing the benefits and costs. Such a framework also needs to include deontological constraints to avoid the possibility that corporations act fanatically by justifying bad actions by reference to an overwhelming social purpose.

\subsection{The critical role of social and corporate purpose}

The final role that social and corporate purpose play is in holding corporations to account for the benefits and harms they create for society. A precondition of exercising this critical function is that societal actors and corporations measure to what extent corporate activities are consistent with corporate and social purpose.

Measures of social purpose can be differentiated into accounting measures and action-guiding measures. An example of an accounting measure in the financial domain is a profit-and-loss statement. A profit-and-loss statement captures to what extent a corporation has achieved its financial objectives in the past. An example of an action-guiding measure in the financial domain is return-on-investment. Returnon-investment is used to compare potential projects ahead of time with a view to selecting the most financially rewarding opportunity.

Most current measures of corporate purpose are accounting measures. Our interview partners reported using measures of environmental, social, and governance impact (ESG) and the 'triple bottom line'.

ESG measures consist of metrics to measure a corporation's impact on the environment, on social issues, and whether the corporation is well governed (Kocmanová \& Šimberová 2014). For instance, a corporation may track its $\mathrm{CO}_{2}$ emissions to measure its impact on the environment. An example of a social metric is the proportion of women in leadership positions.

ESG measures fit with the social responsiveness approach to articulating and pursuing social purpose, as they focus on measuring major societal issues. The advantage of these ways of measuring social purpose is that results are comparable between companies, at least within the same industry. However, ESG measures typically do not directly address the question of to what extent a corporation achieves its corporate purpose.

Of the three components, our interview partners feel most confident that they measure environmental impact accurately. In this area, there is wide consensus on the appropriate measures and on what good looks like, and regulators and other societal actors are relatively effective at holding corporations to account. Concerning the social and the governance components, our interview partners feel less confident that they have good measures in place. Their lack of confidence reflects the lack of consensus on what good looks like, and what the role of corporations is in bringing these about. This is an area where more research would be beneficial for business leaders. 
The 'triple bottom line' is the second widely used approach for measuring corporate purpose (Henriques \& Richardson 2013, Norman \& MacDonald 2004). Similar to the ESG measures, the triple bottom line captures salient societal issues. In contrast to ESG measures, it includes the economic capital of the corporation alongside its ecological and social capital. Taken together, these three 'bottom lines' provide a more holistic picture of the company's performance than just the economic dimension.

Both the ESG framework and the 'triple bottom line' may need to be extended in the light of technological change. Since the methodologies aim to capture salient social issues, they should be extended to include a 'D'-component for data (Pasquale 2015). This component would measure to what extent a corporation behaves transparently and appropriately concerning the use of user data.

None of the methodologies discussed measures corporate and social purpose fully satisfactorily. Solving the measurement challenge is perhaps the most important condition for giving bite to corporate and social purpose. Only where convincing measures are in place, as in the case of environmental measures, can regulators and societal actors be effective at holding corporations to account and enforcing change.

\section{CONCLUSION}

We have argued that there is a broad convergence between different normative perspectives on the view that corporations should serve a social purpose. Moreover, it is difficult to argue that corporations can forego pursuing a corporate purpose, as such a position needs to rely on strong assumptions concerning the social purpose of the corporation and market competition. We have also explored what roles the concepts of social and corporate purpose can fulfil in moral reflection on and of corporations. In particular, we have distinguished the constructive, the communicative, and the critical role of social and corporate purpose. Even if there is, as we have demonstrated, much work to be done in developing the role of purpose in moral reflection on and in corporations, we have shown that the concept of purpose is distinctly useful for such reflection.

\section{REFERENCES}

Altman, M. C. (2007), 'The Decomposition of the Corporate Body: What Kant Cannot Contribute to Business Ethics', Journal of Business Ethics, 74: 253-66.

https://doi.org/10.1007/s10551-006-9233-z

Anderson, E. (2017), Private Government: How Employers Rule Our Lives (Princeton, NJ, Princeton University Press). 
Arnold, D. G. \& Harris, J. D. (2012), Kantian Business Ethics: Critical Perspectives (Cheltenham, Edward Elgar).

Becker, L. C. (1998), 'Reciprocity', in Routledge Encyclopedia of Philosophy (Abingdon, Routledge). https://doi.org/10.4324/9780415249126-L080-1

Bishop, J. D. (2008), 'For-profit Corporations in a Just Society: A Social Contract Argument Concerning the Rights and Responsibilities of Corporations', Business Ethics Quarterly, 18: 191-212. https://doi.org/10.5840/beq200818215

Blair, M. (2003), 'Locking in Capital: What Corporate Law Achieved for Business Organizers in the Nineteenth Century', UCLA Law Review, 51: 387-455.

Brock, G. (1998), 'Are Corporations Morally Defensible?', Business Ethics Quarterly, 8: 703-21. https://doi.org/10.2307/3857549

Bruin, B. de (2015), Ethics and the Global Financial Crisis (Cambridge, Cambridge University Press).

Buzzfeed (2016), 'Maybe Someone Dies in a Terrorist Attack Coordinated on Our Tools'. https://www.buzzfeed.com/ryanmac/growth-at-any-cost-top-facebook-executive-defended-data [accessed 4 March 2018].

Célérier, C. \& Vallee, B. (2013), 'What Drives Financial Complexity? A Look into the Retail Market for Structured Products', Les Cahiers de Recherche No. 1013, HEC, Paris.

Célérier, C. \& Vallee, B. (2015), 'Catering to Investors through Product Complexity', working paper 16-050, Harvard Business School, Cambridge, MA.

Cheney, G., Cruz, I. S., Peredo, A. M. \& Nazareno, E. (2014), 'Worker Cooperatives as an Organizational Alternative: Challenges, Achievements and Promise in Business Governance and Ownership', Organization, 21: 591-603. https://doi.org/10.1177/1350508414539784

Christiano, T. (2010), 'The Uneasy Relationship Between Democracy and Capital', Social Philosophy and Policy, 27: 195-217. https://doi.org/10.1017/S0265052509990082

Ciepley, D. (2013), 'Beyond Public and Private: Toward a Political Theory of the Corporation', American Political Science Review, 107: 139-58. https://doi.org/10.1017/S0003055412000536

Crane, A., Matten, D. \& Moon, J. (2008), Corporations and Citizenship (Cambridge, Cambridge University Press). https://doi.org/10.1017/CBO9780511488542

Dembek, K., Singh, P. \& Bhakoo, V. (2016), 'Literature Review of Shared Value: A Theoretical Concept or a Management Buzzword?', Journal of Business Ethics, 137: 231-67. https://doi.org/10.1007/s10551-015-2554-z

Detomasi, D. (2015), 'The Multinational Corporation as a Political Actor: "Varieties of Capitalism" Revisited', Journal of Business Ethics, 128: 685-700. https://doi.org/10.1007/s10551-014-2099-6

Donaldson, T. (1982), Corporations and Morality (Englewood Cliffs, NJ, Prentice-Hall).

Dunfee, T. W. (2006), 'A Critical Perspective of Integrative Social Contracts Theory: Recurring Criticisms and Next Generation Research Topics', Journal of Business Ethics, 68: 303-28. https://doi.org/10.1007/s10551-006-9016-6

Freeman, R. E., Harrison, J. S., Wicks, A. C., Parmar, B. L. \& Colle, S. de (2010), Stakeholder Theory: The State of the Art (Cambridge, Cambridge University Press). https://doi.org/10.1017/CBO9780511815768

Friedman, M. (1970), 'The Social Responsibility of Business Is to Increase Its Profits', New York Times Magazine 13 September, page SM17.

Gibbard, A. (1991), 'Constructing Justice', Philosophy and Public Affairs, 20: 264-79.

Granovetter, M. (1985), 'Economic Action and Social Structure: The Problem of Embeddedness', American Journal of Sociology, 91: 481-510. https://doi.org/10.1086/228311

Habermas, J. (1985), The Theory of Communicative Action, Volume 2: Lifeworld and System: A Critique of Functionalist Reason (Boston, MA, Beacon Press).

Hansmann, H., Kraakman, R. \& Squire, R. (2006), 'Law and the Rise of the Firm', Harvard Law Review, 119: 1333-403. 
Hasnas, J. (1998), 'The Normative Theories of Business Ethics: A Guide for the Perplexed', Business Ethics Quarterly, 8: 19-42. https://doi.org/10.2307/3857520

Hausman, D., McPherson, M. \& Satz, D. (2016), Economic Analysis, Moral Philosophy, and Public Policy (Cambridge, Cambridge University Press). https://doi.org/10.1017/9781316663011

Heath, J. (2004), 'A Market Failures Approach to Business Ethics', in B. Hodgson (ed.) The Invisible Hand and the Common Good, Studies in Economic Ethics and Philosophy (Berlin, Springer), 69-89. https://doi.org/10.1007/978-3-662-10347-0_5

Heath, J. (2014), Morality, Competition, and the Firm: The Market Failures Approach to Business Ethics (Oxford, Oxford University Press).

https://doi.org/10.1093/acprof:osob1/9780199990481.001.0001

Heath, J., Moriarty, J. \& Norman, W. (2010), ,Business Ethics and (or as) Political Philosophy', Business Ethics Quarterly, 20: 427-52. https://doi.org/10.5840/beq201020329

Henriques, A. \& Richardson, J. (2013), The Triple Bottom Line: Does It All Add Up? (Abingdon, Routledge). https://doi.org/10.4324/9781849773348

Hess, K. (2017), The Unrecognized Consensus about Firm Moral Responsibility (Oxford, Oxford University Press). https://doi.org/10.1093/oso/9780198738534.003.0010

Hsieh, N. (2015), 'The Social Contract Model of Corporate Purpose and Responsibility', Business Ethics Quarterly, 25: 433-60. https://doi.org/10.1017/beq.2016.1

Hsieh, N. (2017), 'The Responsibilities and Role of Business in Relation to Society: Back to Basics?', Business Ethics Quarterly, 27, 293-314. https://doi.org/10.1017/beq.2017.8

Jensen, M. C. (2005), 'Value Maximization, Stakeholder Theory, and the Corporate Objective Function', Journal of Applied Corporate Finance, 14: 8-21. https://doi.org/10.1111/j.1745-6622.2001.tb00434.x

Kim, T. W. \& Strudler, A. (2012), 'Workplace Civility: A Confucian Approach', Business Ethics Quarterly, 22: 557-77. https://doi.org/10.5840/beq201222334

Kocmanová, A. \& Šimberová, I. (2014), 'Determination of Environmental, Social and Corporate Governance Indicators: Framework in the Measurement of Sustainable Performance', Journal of Business Economics and Management, 15: 1017-33.

https://doi.org/10.3846/16111699.2013.791637

Koehn, D. (1995), 'A Role for Virtue Ethics in the Analysis of Business Practice', Business Ethics Quarterly, 5: 533-39. https://doi.org/10.2307/3857397

Lipsey, R. G. \& Lancaster, K. (1956), 'The General Theory of Second Best', The Review of Economic Studies, 24: 11-32. https://doi.org/10.2307/2296233

Logsdon, J. M. \& Wood, D. J. (2002), 'Business Citizenship: From Domestic to Global Level of Analysis', Business Ethics Quarterly, 12: 155-87. https://doi.org/10.2307/3857809

Luhmann, N. (1977), 'Differentiation of Society', The Canadian Journal of Sociology/Cahiers canadiens de sociologie, 2: 29-53. https://doi.org/10.2307/3340510

Marcoux, A. M. (2003), 'A Fiduciary Argument against Stakeholder Theory', Business Ethics Quarterly, 13: 1-24. https://doi.org/10.5840/beq20031313

McMahon, C. (2012), Public Capitalism: The Political Authority of Corporate Executives (Philadelphia, PA, University of Pennsylvania Press). https://doi.org/10.9783/9780812207262

Mitchell, R. K., Agle, B. R. \& Wood, D. J. (1997), 'Toward a Theory of Stakeholder Identification and Salience: Defining the Principle of Who and What Really Counts', Academy of Management Review, 22: 853-86. https://doi.org/10.5465/AMR.1997.9711022105

Néron, P.-Y. (2010), 'Business and the Polis: What Does it Mean to See Corporations as Political Actors?', Journal of Business Ethics, 94: 333-52. https://doi.org/10.1007/s10551-009-0266-y

Néron, P.-Y. (2016), 'Rethinking the Ethics of Corporate Political Activities in a Post-citizens United Era: Political Equality, Corporate Citizenship, and Market Failures', Journal of Business Ethics, 136: 715-28. https://doi.org/10.1007/s10551-015-2867-y 
Néron, P.-Y. \& Norman, W. (2008), 'Citizenship, Inc. Do We Really Want Businesses to Be Good Corporate Citizens?', Business Ethics Quarterly, 18: 1-26. https://doi.org/10.1017/S1052150X00008101

Norman, W. \& MacDonald, C. (2004), 'Getting to the Bottom of "Triple Bottom Line", Business Ethics Quarterly, 14: 243-62. https://doi.org/10.5840/beq200414211

Orts, E. W. (2015), Business Persons: A Legal Theory of the Firm (Oxford, Oxford University Press).

Orts, E. W. \& Smith, N. C. (2017), The Moral Responsibility of Firms (Oxford, Oxford University Press). https://doi.org/10.1093/oso/9780198738534.001.0001

Pasquale, F. (2015), The Black Box Society: The Secret Algorithms That Control Money and Information (Cambridge, MA, Harvard University Press). https://doi.org/10.4159/harvard.9780674736061

Polanyi, K. (2001), The Great Transformation: The Political and Economic Origins of our Time (Boston, MA, Beacon Press).

Porter, M. E. \& Kramer, M. R. (2011), 'Creating Shared Value', Harvard Business Review, 89: 62-77.

Rawls, J. (1996), Political Liberalism (New York, Columbia University Press).

Rawls, J. (1999), A Theory of Justice, rev. edn (Cambridge, MA, Belknap Press).

Santos, F. M. (2012), 'A Positive Theory of Social Entrepreneurship', Journal of Business Ethics, 111: 335-51. https://doi.org/10.1007/s10551-012-1413-4

Scherer, A. G. \& Palazzo, G. (2007), 'Toward a Political Conception of Corporate Responsibility: Business and Society Seen from a Habermasian Perspective', Academy of Management Review, 32: 1096-120. https://doi.org/10.2307/20159358

Scherer, A. G. \& Palazzo, G. (2011), 'The New Political Role of Business in a Globalized World: A Review of a New Perspective on CSR and its Implications for the Firm, Governance, and Democracy', Journal of Management Studies, 48: 899-931. https://doi.org/10.1111/j.1467-6486.2010.00950.x

Scherer, A. G., Rasche, A., Palazzo, G. \& Spicer, A. (2016), 'Managing for Political Corporate Social Responsibility: New Challenges and Directions for PCSR 2.0', Journal of Management Studies, 53: 273-98. https://doi.org/10.1111/joms. 12203

Sollars, G. G. (2002), 'The Corporation as Actual Agreement', Business Ethics Quarterly, 12: 351-70. https://doi.org/10.2307/3858021

Solomon, R. C. (1993), Ethics and Excellence: Cooperation and Integrity in Business (New York, Oxford University Press).

Stout, L. A. (2012), The Shareholder Value Myth: How Putting Shareholders First Harms Investors, Corporations, and the Public (Oakland, CA, Berrett-Koehler Publishers).

Sundaram, A. K. \& Inkpen, A. C. (2004), 'The Corporate Objective Revisited', Organization Science 15: 350-63. https://doi.org/10.1287/orsc.1040.0068

Vaughan, S. K. \& Arsneault, S. (2018), 'The Public Benefit of Benefit Corporations', PS: Political Science and Politics, 51: 54-60. https://doi.org/10.1017/S1049096517001391

Wood, D. J. (1991), 'Corporate Social Performance Revisited', Academy of Management Review, 16: 691-718. https://doi.org/10.5465/AMR.1991.4279616

Zingales, L. (2015), 'Does Finance Benefit Society?', working paper 20894, National Bureau of Economic Research, Cambridge, MA.

Notes on the authors:

Nien-hê Hsieh is an Associate Professor of Business Administration in the General Management Unit of Harvard Business School. His research concerns ethical issues in business and the responsibilities of global business leaders.

nine-he@principia-advisory.com 
Jens van 't Klooster is a Max Weber Fellow at the European University Institute. He has a $\mathrm{PhD}$ in philosophy from the University of Cambridge. His research focuses on the politics of financial markets.

Jens.vantklooster@eui.eu

Twitter: @jensvantklooster

Marco Meyer is a Leverhulme Early Career Research Fellow at the University of York. He has a PhD in philosophy from the University of Cambridge and a $\mathrm{PhD}$ in economics from the University of Groningen. His research interests include organisational ethics, applied epistemology, and global justice.

marco.meyer@york.ac.uk.

David Rodin is Part Time Professor at the European University Institute in Florence and CEO of Principia Advisory, a consultancy specialising in organisational ethics and culture change.

david@principia-advisory.com

To cite the article: Nien-hê Hsieh, Marco Meyer, David Rodin and Jens van 't Klooster (2018), 'The social purpose of corporations', Journal of the British Academy, 6(s1): 49-73.

DOI https://doi.org/10.5871/jba/006s1.049

This article is licensed under a

Creative Commons Attribution-NonCommercial-NoDerivs 4.0 Unported License.

Journal of the British Academy (ISSN 2052-7217) is published by

The British Academy - the national academy for the humanities and social sciences.

10-11 Carlton House Terrace, London, SW1Y 5AH

www.britac.ac.uk 
